\title{
Understanding Cross Cultural Through PBL For Higher Education Students at UNIMUDA Sorong
}

\author{
$1^{\text {st }}$ Raisa Anakotta ${ }^{1}, 2^{\text {nd }}$ Mustika Irianti ${ }^{2}, 3^{\text {rd }}$ Solehun $^{3}$ \\ \{anakotta12@gmail.com $\left.{ }^{1}, \underline{\text { zteccanism@gmail.com }}{ }^{2}, \underline{\text { hun.solehun@gmail.com }}{ }^{3}\right\}$ \\ Universitas Pendidikan Muhammadiyah Sorong, West Papua, Indonesia
}

\begin{abstract}
Higher education students in Papua were different with those in Java or other regions. They needed intensive and special treatment to make them eager to learn the subject taught. This research aimed at knowing the influence of PBL method on the basis of local wisdom and describing the application of PBL method on the higher education students at STKIP Muhammadiyah Sorong. This quasi-experimental research used one group pretestposttest design. The data was collected using observation, questionnaire and test. The obtained data was analyzed using normality test and hypothesis test. The steps of PBL method were initiating theme or topic, organizing the assignment in group, preparing the result of report, presenting and evaluating the result report. Those steps would be effective if the lecturer controlled the every single step in each groups. The analysis result showed that there was positive improvement when PBL method applied to the higher students. Based on regression test, the score of t-hitung was 2,371 with significance value $0,035<0,05$. Thus, it could be concluded that $\mathrm{H} 1$ was accepted and $\mathrm{H} 0$ was rejected. It meant that PBL method based on local wisdom was effective enough to be applied to the higher students in STKIP Muhammadiyah Sorong.
\end{abstract}

Keywords: problem based learning, cross cultural understanding, local wisdom, STKIP Muhammadiyah Sorong

\section{Introduction}

On the higher education level, the students were prepared to learn independently with the guidance of the lecturer. The lecturer only acted as a facilitator who gave guidance and directed the students to actively learning. The lecturer then should have appropriate methods to make those teaching and learning process succeed.

However, that kind of teaching and learning process could not applied easily in West Papua. To create those kinds of interaction, the lecturer needed extra efforts both in using teaching method and in creating effective learning atmosphere. The teaching and learning process at Higher Education in West Papua has no significant differences with the ones at schools. The students were still passive learners while the lecturer must deliver the whole material to the students. The students' activeness and independence was still low.

The other obstacles happened was in teaching way. Lecturers frequently only focused on the intellectual aspect in which they just discussed about the materials. Whereas, a good teaching 
occurred when in the teaching process the lecturer also delivered social, character or cultural values. Cultural value which was the basic for nation character was one of the important thing to be taught to every individuals. The various society and culture in Sorong could make the teaching and learning process more meaningful if only it was implemented in the teaching and learning process. Therefore, in teaching and learning process, it was needed a method that could be used to improve the students understanding on various cultures they faced. Teaching and learning process based on local wisdom was a learning process which based on the cultures that exist on the environment of the society or students.

Problem based learning (PBL) method based on local wisdom was considered to be able to deal with the learning obstacles explained above. PBL referred to sequence activities which focused on the process of solving the problem given scientifically (Sanjaya, 2009: 214). Through the given problems, students would try to find the solution based on the knowledge they had before. So that they could find the correlation between the previous materials with the new one that they learn and how it applied in contextually.

\section{Method}

This research was quasi experimental research which applied one group pretest-posttest design. This research was conducted to English Department students of STKIP Muhammadiyah Sorong on even semester for academic year 2017/ 2018. The sampling technique used was purposive sampling that was students of VI semester who already take Cross Cultural Understanding Subject with the total number were 14 students. The data was collected by observation, questionnaire and test. This research was begun with initial survey to review the methods used by the lecturer. Then, the researcher conducted screening to collect pretest score which continued by applying PBL method based on local wisdom. The last, the students were given posttest to determine the improvement. The obtained data was analyzed using normality test and hypothesis test.

\section{RESULT AND DISCUSSION}

\section{Result}

Pre-test

Before applying PBL method based on local wisdom, the students were given pretest. Previously, the pretest has been validated by the expert. Here was the result of pretest as follows: 


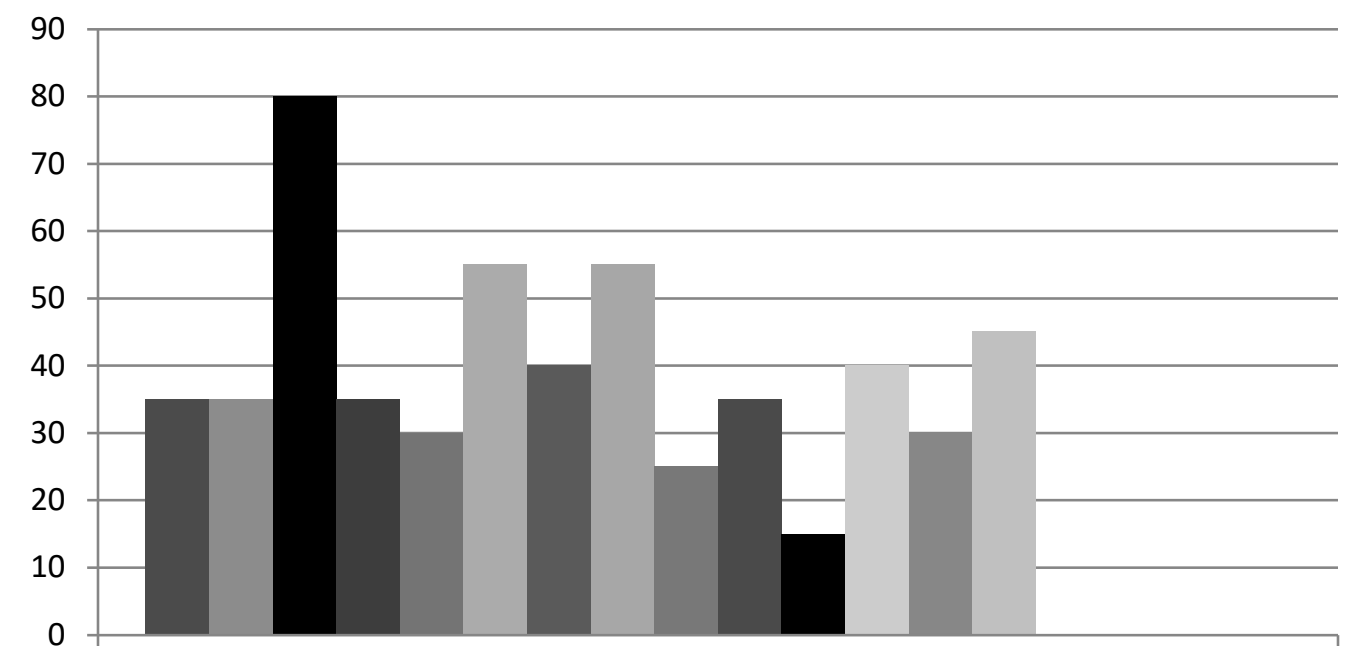

Fig 1. Diagram of pretest score

The diagram above showed the pretest score of 14 students. The highest score was 80 while the lowest score was 15. The diagram above showed that the students result on cross cultural understanding was low.

\section{The Application of PBL method based on Local Wisdom}

Before this research was conducted, the students have not known about PBL method at all so as to the method applied, they were enthusiastic. The steps of PBL method based on local wisdom were begun with (a) giving theme or topic; (b) organizing the assignment in group; (c) designing the sequence activities to solve the problem; (d) starting investigation with group; (e) preparing the result in the form of report which then (f) presented in front of the class in the form of power point slide; and the last (g) evaluating the group result. The application of PBL method was conducted in several meeting. The first meeting was planning and the other meetings were conducting field observation and presentation.

\section{Posttest}

Posttest was given after PBL method based on local wisdom has been done. The result of posttest was as follows: 


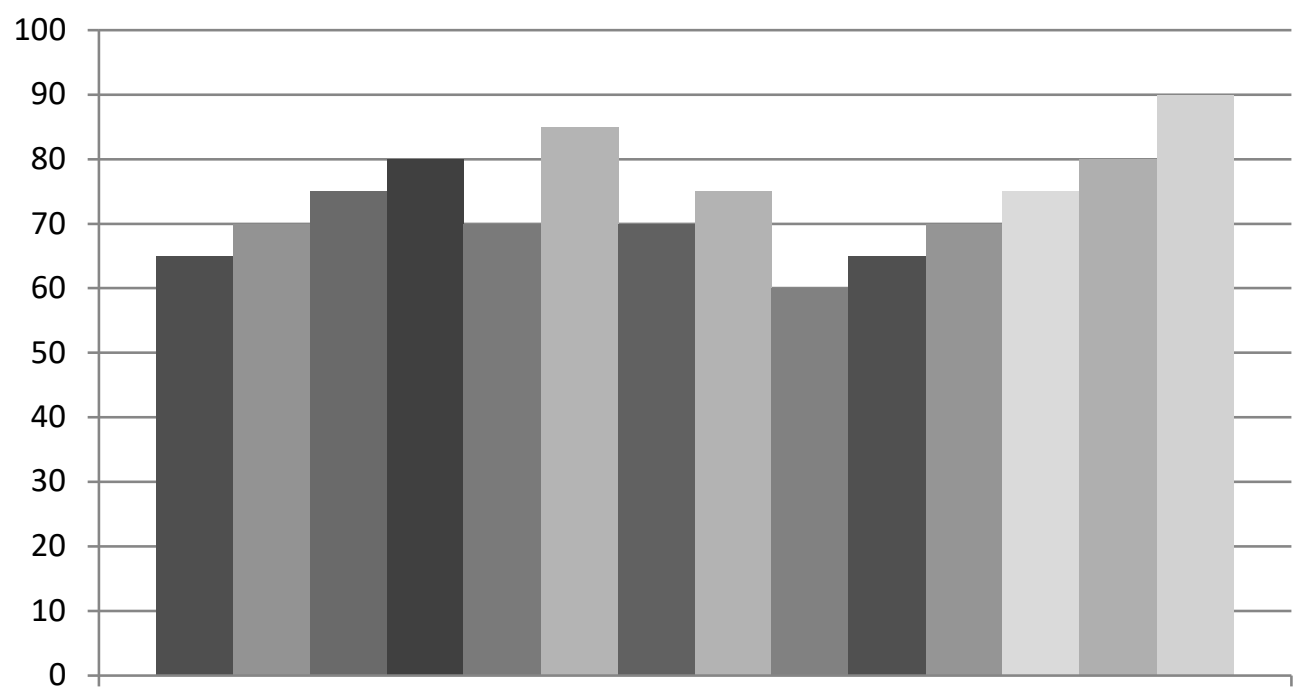

Fig 2. Diagram of Posttest score

Fig 2 showed the highest score was 90 and the lowest score was 60 . The scores indicated that there was a significant improvement toward students result.

\section{Questionnaire}

The result of questionnaire indicated that there was a good respond from the students about PBL method based on local wisdom. In one of the statements showed that PBL method based on local wisdom was a new method for the students.

\section{Normality Test of Pretest}

The normality test was obtained from pretest score. With significant level of 0,05 , it could be obtained the normality test as follows:

Table 1. Test of Normality of Pretest

\begin{tabular}{|c|r|r|r|r|r|r|}
\hline & \multicolumn{3}{|c|}{ Kolmogorov-Smirnov $^{\mathrm{a}}$} & \multicolumn{3}{c|}{ Shapiro-Wilk } \\
\cline { 2 - 7 } & Statistic & \multicolumn{1}{c|}{ df } & \multicolumn{1}{c|}{ Sig. } & Statistic & \multicolumn{1}{c|}{ df } & Sig. \\
\hline pretest & .205 & 14 & .113 & .902 & 14 & .120 \\
\hline
\end{tabular}

a. Lilliefors Significance Correction 
Based on the table above, it indicated that significant score was $0,113>0,05$. Thus, it could be concluded that the pretest data was distributed normally.

\section{Normality Test of Posttest}

Normality test was measured using software SPSS for windows. With significant level of 0,05 , it could be obtained the normality test as follows:

Table 2. Test of Normality of Posttest

\begin{tabular}{|l|r|r|r|r|r|c|}
\hline \multirow{2}{*}{} & \multicolumn{3}{|c|}{ Kolmogorov-Smirnov $^{\text {a }}$} & \multicolumn{3}{c|}{ Shapiro-Wilk } \\
\cline { 2 - 7 } & Statistic & \multicolumn{1}{c|}{ df } & \multicolumn{1}{c|}{ Sig. } & Statistic & \multicolumn{1}{c|}{ df } & Sig. \\
\hline tes & .169 & 14 & $.200^{\circ}$ & .964 & 14 & .787 \\
\hline
\end{tabular}

*. This is a lower bound of the true significance.

a. Lilliefors Significance Correction

Based on the table above, it indicated that significant score was $0,200>0,05$ so that it could be concluded that the posttest data was distributed normally. Since the posttest data was normally distributed, it could be continued with hypothesis test.

\section{Normality Test of Questionnaire}

The statements on the questionnaire were 24 items. The questionnaire was distributed after the PBL method based on local wisdom applied. Based on the questionnaire it was obtained the respond of the use of PBL method. The questionnaire result then analyzed with posttest result on the step of hypothesis test.

With significant level of 0,05 , it could be obtained the normality test as follows:

Table 3. Test of Normality of Questionnaire

\begin{tabular}{|c|r|r|r|r|r|c|}
\hline \multirow{2}{*}{} & \multicolumn{3}{|c|}{ Kolmogorov-Smirnov $^{\mathrm{a}}$} & \multicolumn{3}{c|}{ Shapiro-Wilk } \\
\cline { 2 - 7 } & Statistic & \multicolumn{1}{c|}{ df } & \multicolumn{1}{c|}{ Sig. } & Statistic & \multicolumn{1}{c|}{ df } & Sig. \\
\hline angket & .175 & 14 & .200 & .943 & 14 & .463 \\
\hline
\end{tabular}

*. This is a lower bound of the true significance.

\section{a. Lilliefors Significance Correction}

Based on the table above, it indicated that significant score was $0,200>0,05$ so that it could be concluded that the posttest data was distributed normally. Since the posttest data was normally distributed, it could be continued with hypothesis test.

\section{Hypothesis Test}

The hypothesis test measured using simple regression test. The regression test used the result of posttest and questionnaire. The result of regression test was as follows: 
Table 4. Result of variables entered and removed

\begin{tabular}{|l|l|l|l|}
\hline Model & $\begin{array}{c}\text { Variables } \\
\text { Entered }\end{array}$ & $\begin{array}{c}\text { Variables } \\
\text { Removed }\end{array}$ & Method \\
\hline 1 & angket $^{b}$ & & Enter \\
\hline
\end{tabular}

a. Dependent Variable: tes

b. All requested variables entered.

Table 5. Model Summary

\begin{tabular}{|l|r|r|r|r|}
\hline Model & $\mathrm{R}$ & R Square & $\begin{array}{c}\text { Adjusted R } \\
\text { Square }\end{array}$ & $\begin{array}{c}\text { Std. Error of } \\
\text { the Estimate }\end{array}$ \\
\hline 1 & $.565^{\mathrm{a}}$ & .319 & .262 & 7.032 \\
\hline
\end{tabular}

a. Predictors: (Constant), angket

Table 6. ANOVA

\begin{tabular}{|c|c|c|c|c|c|c|}
\hline Model & & $\begin{array}{l}\text { Sum of } \\
\text { Squares }\end{array}$ & $\mathrm{df}$ & Mean Square & $\mathrm{F}$ & Sig. \\
\hline 1 & Regression & 277.988 & 1 & 277.988 & 5.621 & $.035^{\mathrm{b}}$ \\
\hline & Residual & 593.441 & 12 & 49.453 & & \\
\hline & Total & 871.429 & 13 & & & \\
\hline
\end{tabular}

a. Dependent Variable: tes

b. Predictors: (Constant), angket

Table 7. Coefficients

\begin{tabular}{|c|c|c|c|c|c|c|}
\hline \multirow[b]{2}{*}{ Model } & & \multicolumn{2}{|c|}{ Unstandardized Coefficients } & \multirow{2}{*}{$\begin{array}{c}\text { Standardized } \\
\text { Coefficients }\end{array}$} & \multirow[b]{2}{*}{$\mathrm{t}$} & \multirow[b]{2}{*}{ Sig. } \\
\hline & & $\mathrm{B}$ & Std. Error & & & \\
\hline & (Constant) & 35.951 & 15.979 & & 2.250 & .044 \\
\hline & angket & .507 & .214 & .565 & 2.371 & .035 \\
\hline
\end{tabular}

a. Dependent Variable: tes 
Based on regression test, it indicated that the score of t- hitung was 2,371 with signivicant value was $0,035<0,05$.

\section{Discussion}

Pretest and Posttest Result by Applying PBL method based on Local Wisdom

Based on the result of pretest and posttest, it could be seen that the score before treatment using PBL method based on local wisdom was mostly under the average score. Meanwhile, after applying PBL method based on local wisdom, the students result was improved significantly. Thus, it could be concluded that PBL method based on local wisdom has significant influence toward students learning in the class. Although using different method than others Susiani (2015), Wibawa (2015), Tany, Yunita S dan Tri Hapsari U (2015) and Hadi (2016), this study still could show the significant improvement of the PBL method. However, in the subjects and in the context of higher education students in West Papua, the application of PBL was little bit different with others. PBL method actually trained students to be independent, critical and do team work. However, in this study, it found that if the PBL method was only applied by giving instruction, it would not run well. The lecturer has to always control, check and guide the groups in doing the PBL steps so that they could understand and were willing to do the method in the learning process as well. Some of the causes were the lack of motivation to learn and they were not used to be independent learning.

\section{Regression Test Result}

The hypotheses in this research were:

$\mathrm{H}_{0}=\mathrm{PBL}$ method based on local wisdom has no significant influence toward students understanding on cross culture

$\mathrm{H}_{1}=$ PBL method based on local wisdom has significant influence toward students understanding on cross culture

Based on the table of regression test, it showed that the score of $t$ hitung was 2,371 with significant value was $0,035<0,05$. It meant that Ho was rejected and H1 was accepted, namely there was significant influence of PBL method based on local wisdom (X) toward students' understanding result $(\mathrm{Y})$.

\section{Conclusion}

PBL method was a method that commonly used starting from schools level to higher education level. However, it was still considered as a new method for students in West Papua. Sometimes, the steps of any method especially PBL method should have been modified to ease the students understanding in following it. Therefore, the PBL method based on local wisdom was appropriately fit with the way of learning of higher students in West Papua because it already adjusted to the students' level and contextually fit with students' daily life. It also supported with 
the students' test result which showed significant improvement and their interest on the PBL method based on local wisdom based on the statement valued in the questionnaire.

\section{References}

[1] Agrina, Reni, Zulfitri \& Herlina.(2012). Metode drill studi kasus dalam meningkatkan hasil belajar asuhan keperawatan keluarga. Jurnal Keperawatan. ISSN 2086-3071.Volume 3. No 2.

[2] Amir, M. Taufiq.(2009). Inovasi Pendidikan Melalui Problem Based Learning. Jakarta: Kencana

[3] Arends, Richard I.(2008). Learning to Teach. Yogyakarta: Pustaka Pelajar

[4] Hadi, Fida R. (2016). Penerapan Pembelajaran Problem Based Learning (PBL) untuk Meningkatkan Hasil Belajar Matematika Siswa Kelas IV Jurnal Profesi Pendidikan Dasar Vol 3, No. 2.IKIP Madiun.

[5] Muldyahatmi.Sri. (2013).Problem Based Learning Dan Pemahaman Siswa Terhadap Masalah Sosial Di Masyarakat. Surakarta: LPPM UNS. Dalam Jurnal of Rural and Development Volume IV No. 2 Agustus 2013

[6] Rusmono. (2012). Strategi Pembelajaran dengan Problem Based Learning itu perlu. Bogor: Ghalia Indonesia.

[7] Susiani, Aftika. (2015). Penerapan Model Pembelajaran Problem Based Learning (PBL) untuk Meningkatkan Hasil Belajar Sosiologi Siswa Kelas X IIS 5 SMA Negeri 8 Surakarta Tahun Ajaran 2014/2015. Surakarta: Universitas Sebelas Maret

[8] Sutomo, Edi. (2017). Efektivitas Penerapan Model Pembelajaran Project-Based Learning Terhadap Minat, Keaktifan dan Hasil Belajar Pada Materi Konsep Dasar IPA Mahasiswa PGSD Semester gasal tahun akademik 2016/2017. Jayapura: Universitas Cendrawasih 